\title{
REVITALISATION OF SUMBA WOVEN INTO FASHION PRODUCT FOR URBAN PEOPLE AS A TARGET MARKET
}

\author{
Yosepin Sri Ningsih \\ (Email: putrisavu@gmail.com) \\ Program Studi D3 Seni Rupa dan Desain \\ Fakultas Seni Rupa dan Desain \\ Universitas Kristen Maranatha \\ JL. Prof. Drg. Surya Sumantri No.65, Bandung, Indonesia
}

\begin{abstract}
ABSTRAK
Salah satu daerah yang memiliki kekuatan khas dari segi kriya tekstilnya adalah propinsi NTT (Nusa Tenggara Timur), yang dikenal dengan kekhasan tenunnya. Kekhasan yang dimiliki oleh tenun NTT membuat beberapa bidang seperti pariwisata dan kebijakan politik selanjutnya memiliki pengaruh terhadap keberadaan tenun NTT. Pengaruh tersebut antara lain perubahan fungsi tenun dari adati menjadi produk ekonomis yang kemudian berdampak pada perubahan material serta metode pemanfaatan tenun. Material yang digunakan saat ini sudah lebih modern dengan menggunakan benang yang dapat dibeli di pasar hasil impor dari pulau lain atau negara lain, sedangkan pemanfaatan tenun yang tadinya hanya digunakan secara adat saat ini telah dipotong menjadi baju siap pakai dengan bentuk yang lebih modern mengakibatkan adanya bagian tenun yang terbuang. Berangkat dari kondisi tersebut, peneliti mengembangkan produk busana sebagai bentuk revitalisasi tenun ikat dalam menjawab kebutuhan busana dengan material utama tenun NTT bagi para konsumen. Tenun NTT yang dipilih ke dalam penelitian adalah Tenun Sumba, karena corak yang terdapat pada tenun Sumba memiliki tingkat kerumitan lebih tinggi ketimbang tenun NTT lainnya seperti bentuk-bentuk makhluk hidup dengan ukuran besar yang berbeda dengan tenun dari pulau lain yang lebih banyak bernuansa geometris. Bentuk dan komposisi corak yang besar dan terkait dengan mitos maupun makhluk hidup selama ini menjadi kendala bagi para desainer dalam memanfatkan material tenun Sumba menjadi busana. Dengan menggunakan pendekatan metode penelitian deskriptif kualitatif yang dipilih yaitu minimalism as a counter culture yang dipopulerkan oleh Rei Kawakubo serta pendekatan market research, peneliti sekaligus desainer membuat konsep busana dengan mengoptimalkan penggunaan kain. Dengan metode ini peneliti dapat menghasilkan produk busana tanpa menyisakan bagian tenun yang tidak berpotensi lagi untuk diolah ke dalam produk busana atau produk lainnya sekaligus menjawab kebutuhan market yang memiliki apresiasi tinggi terhadap karya tenun.
\end{abstract}

Kata Kunci: busana siap pakai, desain, tenun Nusa Tenggara Timur, tenun Sumba, revitalisasi 


\section{ABSTRACT}

One of the areas that has special strength in terms of textile craft is NTT (East Nusa Tenggara) province, which is known for its unique weaving. The peculiarities of NTT woven make several fields such as tourism and political policy subsequently have an influence on the existence of NTT woven. These influences include changes in the function of weaving from adati to economical products, which then have an impact on material changes and methods of using weaving. The material used today is more modern by using threads that can be purchased in the market from imports from other places, while the used of weaving in ritual way has now been cut into ready-made clothes with a more modern form that sometimes produced leftover materials. Departing from these conditions, researchers develop fashion products as revitalization of NTT woven in order to fulfill the consumer needs. The NTT woven that chosen in this case is Sumba woven, because the patterns found in Sumba woven have a higher level of complexity than other NTT woven such as large living forms that are different from woven from other islands with more geometric nuances. The shape and composition of the large patterns and forms associated with myths and living things have been an obstacle for designers in creating cloth from these materials. By using the descriptive qualitative method, minimalism pattern, which is popularized, by Rei Kawakubo and the market research approach then researchers create a fashion concept by optimizing the use of cloth. Hence, researchers can produce fashion product without leaving a weaving parts that has no potential to be processed into other products as well as answering the needs of the market whose has a high appreciation of the weaving process.

Keywords: design; East Nusa Tenggara woven, fashion product; Sumba woven; revitalization

\section{INTRODUCTION}

Fashion design by utilizing local resources, both from cultural and material elements, has been developing and continued to go through some changes until this day. Those changes are influenced by various factors such as advances in science, tourism, and political policies in a certain region. Those various changes then emerge the trends in fashion world, one of which is the high market interest on local nuanced fashion products. Clothing products featured with certain region locality strengths have been sought back by the market and purchased at varying prices depending on the design and material quality. Various traditional textile uniqueness from different region has then become popular.

The influence on traditional textiles is not only on technique and design but also on function and significance. These changes occur as a form of adjustment to new circumstances, new political structures, as well as new belief systems (Maxwell, 2003: 24). One obvious example of changes in Indonesian textiles was originally seen on batik. The popularity of batik in Indonesia and the world was strongly supported by political events, which subsequently influenced various other segments. In the era of Soeharto (2nd President of Indonesia from 1965 to 1998), batik began to be worn as garments in welcoming state guests, until its peak at that time Soeharto specially ordered Iwan Tirta to make batik design for the 17 countries participating in APEC in Indonesia in 1994 (Http://baltyra.com/2009/10/02/soeharto-pemantik-batik/). Batik, with the support of industrial and economic conditions in Java Island, then had become increasingly popular 
and can be worn every day in various regions in Indonesia as far as abroad and gained inaugural from the UNESCO as a cultural heritage in 2009.

Having seen the popularity of batik, many regions in Indonesia tried to develop the traditional patterns that were then applied using batik techniques. However, this thing needed not to be done by the regions that already had had eminences in traditional textiles. One of the regions is the NTT (East Nusa Tenggara) region with its weaving potential, so that the local government affirmed the regulation on the use of woven fabrics as work clothes in government employee's environment in 2009 (Pollock, 2012). That was done by the government in order to raise the popularity of weaving and increase the economy activities in NTT. That meant that not every region in Indonesia had to develop batik as local potential, instead those regions could start developing it from the existing potential.

Nawacita, as President Joko Widodo's (President of Indonesia from 2015) program, strongly supports the realization of Smart Indonesia, Working Indonesia, and Prosperous Indonesia (Kompas: 2014). This program is prioritized for regions that have low infrastructure and socio-economic development in Indonesia, which one of them is NTT. This program has been increasingly supporting weaving as NTT's local potential to be raised and popularized into a wider community scope, not only in NTT local community. There are still many lovers of local Indonesian products that have not recognized the uniqueness of traditional weaving. It was shown in market interview results in INACRAFT 2017, the biggest annual craft exhibition event in Indonesia. Most of the consumers had not grasped the textile uniqueness in Indonesia other than batik. The author, through this research, has then raised weaving from NTT region to be utilized into fashion products in order to increase market interest and awareness of weaving uniqueness from east region of Indonesia.

The design of fashion products by utilizing NTT weaving certainly had its own challenges associated with its pattern character and unique material. These precious elements then must be shown into product which wider number of people can appreciate. As a descriptive qualitative research, in the way to fulfill that purpose, designer cannot take such conditions or characteristics or feelings into account unless they are available either by this research volition or by the impact of others (Knowles, 2008: 11). Then designer chose minimalist style approach with the consideration that the targeted market was urban 
people that has the characters of smart and having interest towards Indonesian textiles. Urban people was chosen as the target market because urban people have great potential in popularizing products rapidly through lifestyles that they display through their daily activities with the support of high social media activities in urban environment these days. Transfer of knowledge into wider community scope was expected to occur on the uniqueness of traditional textile, especially the weaving from NTT region.

\section{RESEARCH METHODS}

In the last few decades of the $20^{\text {th }}$ century, qualitative research in the social sciences began to pay serious attention to the use of image to enhance their understanding of the human condition. This research is categorized as descriptive qualitative research because the process of making and choosing each element doesn't use certain calculation. Each stages of the process are decided by reasonable aspects, which had been surveyed through location and omniscience member related to this research. As was mentioned before, the material that had been chosen in this project is woven from NTT, especially Sumba woven which has strong image characteristic. Sandra Weber said that these specific images can mean or represent at any given time depends on a lot of factors, including who is doing the viewing and the context in which the image is viewed. Major Scholars, from the late $19^{\text {th }}$ and early $20^{\text {th }}$-century semioticans Charles Peirce, Ferdinand de Saussure, Jean Baudrillard, Roland Barthes and John Berger have addressed the slippery question of how images mean, providing a variety of sophisticated and nuanced models to guide the use of images in contemporary work. For example, Barhtes posits that images have two levels of meaning: denotative and connotative. The denotative meaning of an image refers to its literal, descriptive meaning/ the apparent truth, evidence or objective reality that the image documents or denotes. The same image also connotes more culturally specific meanings. Connotative meanings refer to the cultural and historical context of a specific image, as well as to the social conventions, codes and meanings that have been attached to or associated with that image in a particular context (Knowles, 2008:42).

In the term to cultivate the material, designer must knowing the material comprehensively from the process of making until the meaning of the images. Then the process of this research always entwine the connotative meanings of the image into the outcome by devided the process into 3 stages. The first stage is respectively research on local potential object (which in this case was lkat Weaving), the second is market research, and the last 
stage is the design production of fashion collection. The applied theoretical approach was "minimalism pattern", that is the optimal textile utilization by minimizing cloths disposal. This method is part of minimalism style in fashion. The style of "minimalism as a counter culture" was popularized by avant-garde designers Issey Miyake, Yohji Yamamoto, and Rei Kawakubo that started being popularized in the 1980s and was seen as a new orientalism in the fashion world (Walker, 2011: 69). Based on the extent of urban community activities, as the main market, this style was considered suitable as a silhouette approach of fashion collection utilizing NTT weaving.

\section{NTT and lkat Weaving of East Sumba}

NTT as an archipelago region in Central Indonesia has quietly stolen the attention of abroad audiences. Documentation on NTT, which especially related to textile culture, is found more on various foreign-language universities websites and libraries than Indonesian itself. Journals writing about NTT began to be found in foreign travel records since the 17th century, when expedition voyages for both science and economics, were competed by foreign ships (Miller, 2011: introduction). The records were made by the Captains of the Ships (James Cook in 1770, William Bligh in 1789), botanists and naturalists (Russell Alfred Wallace in 1854, Henry Forbes in 1882), anthropologists (James Fox 1977, Roy Hamilton in 1994). Researchers found, through various documentations, interesting tendency to elude unique local clothing in the eyes of the explorers, as well as that the textiles from this region had an important role and were used as a gift to explorers by the local king.

The NTT region is a group of 550 islands united in Savu Sea. Its 3 large islands are Sumba in the west, Flores in the north, and Timor in the east. These regions have its own distinct weaving characteristics in their patterns, materials, and manufacturing techniques. Based on researcher's field visits starting in 2013, each region had its own uniqueness, especially when they were observed from the patterns produced. The researcher had found significant distinctions from those various uniqueness of Sumba weaving characteristics, especially on East Sumba region, which could be seen in the ornamentation objects in its weaving fabrics. Based on that reason, researcher decided to focus on the objects of East Sumba weaving in this research. 


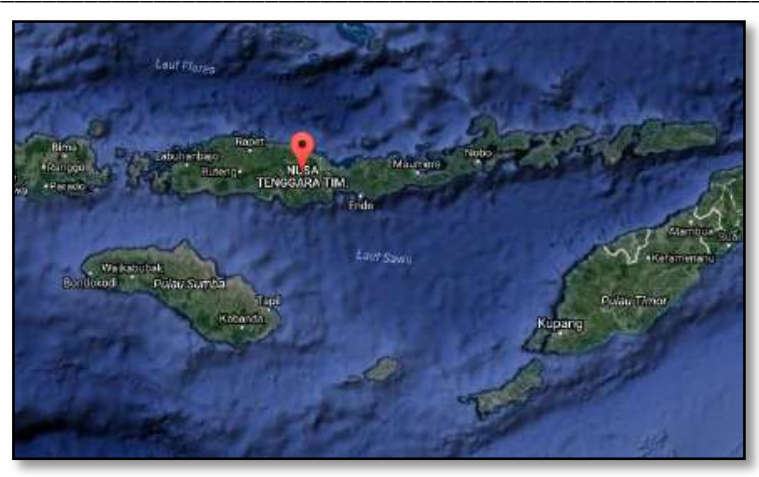

Figure 1. Map of East Nusa Tenggara Province

Source: Downloaded from http://www.mapnall.com/id/Peta-Nusa-Tenggara-Timur_1104177.html on 21 September 2016, 09.16 AM of West Indonesia Time

Weaving from East Sumba region, or better known as Hinggi, belongs to 'warp ikat weaving' category when observed from its manufacturing structure. Warp lkat is the oldest ikat weaving that is widely used by certain people in Indonesia such as Batak people in Sumatra, Dayak people in Borneo, Toraja people in Sulawesi and Nusa Tenggara people (Jay, 2014: 16). When observed from its pattern, ikat weaving from East Sumba region has the pattern of real living creatures as well as mythological creatures with the composition consisting of large and small size forms in an average piece of cloth sized 1-1.5 $\mathrm{m}$ of width and about 2- $3.5 \mathrm{~m}$ of length. Figurative forms that often appear are horses, dogs, deer, monkeys, and many other animals which are arranged to be looking face to face. Horses are believed to be nationalities animal, dogs are associated with fighters, and deer are the symbolic of kings. Snakes and crocodiles are associated with rebirth and longevity, as well as life after death. Other patterns featured in Hinggi are chickens as a symbol of masculinity and trees as a symbol of fertility.

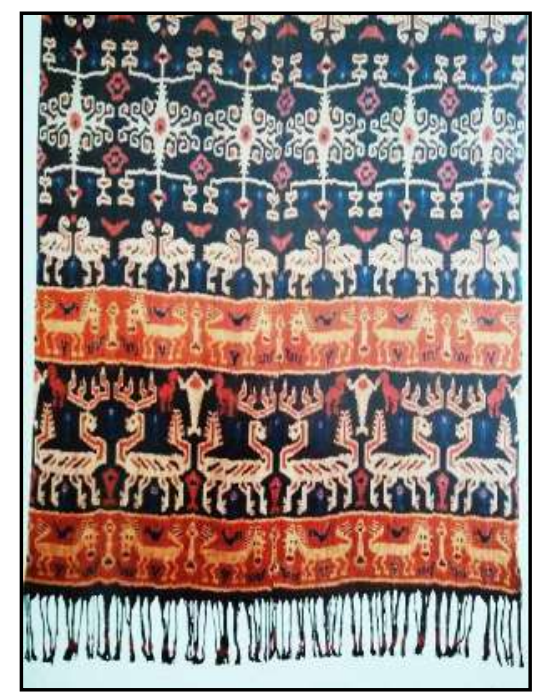

Figure 2. An Example of Hinggi, ikat weaving from East Sumba. Source: Ratna Panggabean Collection (Jay, 2014: 17) 


\section{Market Research}

Market analysis and trending reference are required in the fashion products design process so that the resulting products can be well presented to the consumers. Market analysis is conducted by determining the segmentation, targeting, and positioning of the collections to be produced. Segmentation and consumer targeting of these local nuanced products were urban people who have interests on local culture, have the income of middle to upper social strata, have awareness of their appearances, and behave intelligently. After recognizing the targeted market segmentation, the designer needed to conduct positioning towards peer industry competitors in order to provide different, even better characteristic than the products that were already circulating in the market.

Since the birth of Nawacita program that prioritizes local-based economy, many industry practitioners have attempted to raise the local potentials of certain regions, not only on fashion, but also on arts and other design fields such as films, music, and advertising. This has made various actions featuring local culture to be demanded by the market. Sumba, which is one of the remote areas compared to other islands in NTT (and low development level of NTT among 34 other provinces in Indonesia), has obtained great effects through "Pendekar Tongkat Emas" (2014) movie that displays the panoramic power and weaving culture activities. Since then, various fashion practitioners have put efforts to feature weaving into their line of clothing. Various brands that have been popularizing weaving to this day are "Sejauh Mata Memandang", "Lekatdihati", "Ikat", “LuluLutfiLabibi", “LemariLila”, and "Dian Oerip" with their simple and affordable middle-class prices. Weaving also had been previously popularized by several Indonesian designers such as Ghea Panggabean, Didit Maulana, Didi Budiharjo, Samuel Watimena, and Mel Ahyar but with the allocation for special event and was only affordable for the upper elites and socialite class.

Each brand has its own uniqueness and market. Going through segmentation, targeting, and positioning, the characteristic of this collection is concluded to be as follows: 


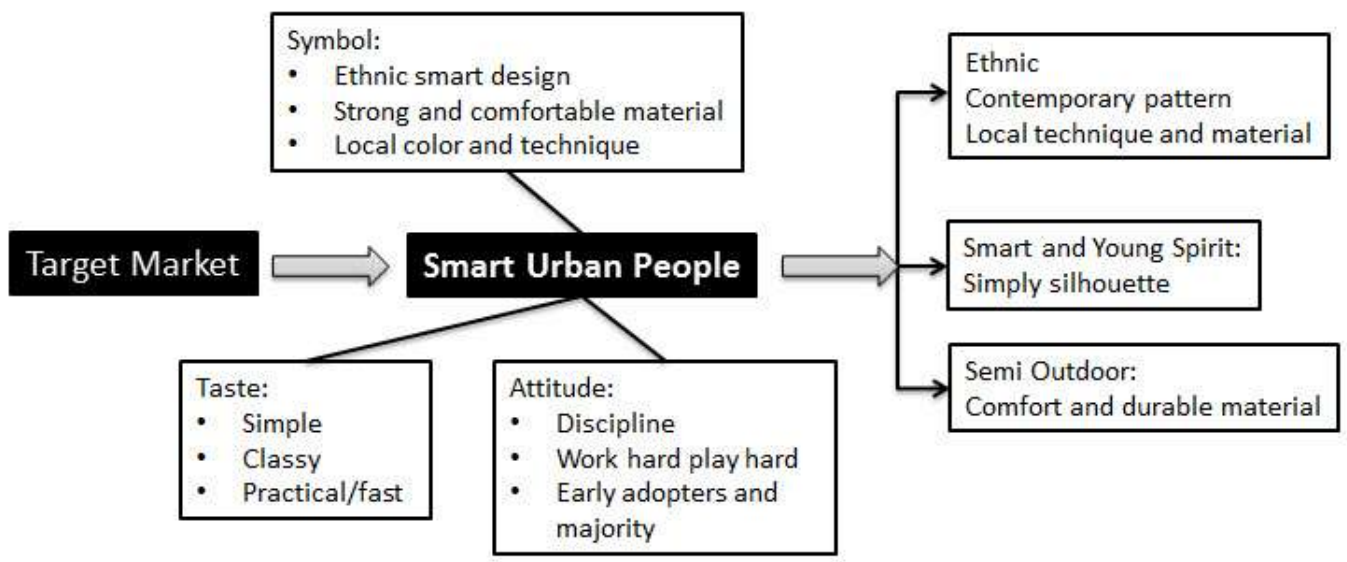

Figure 3. Target Market Character of Every Day with Sumba Collection Source: Ningsih, 2017

\section{Minimalist Pattern}

Miyake, Yamamoto and Kawakubo are the designers who made a big influence in the development of minimalist style in fashion world. Minimalist style that was carried out by these three Japanese designers had an avant-garde character in the 80s and has since become a new trend carried by Asia (New Oriental).

Issey Miyake is known as the architect of fabric for his expertise in manipulating fabric into a complex structure that cocoons the body. Miyake, in his works, emphasizes the distance created between the fabric and the body that manages to give a natural freedom for the body. Yohji Yamamoto is known for his character of east-west combination and matching in undirectional silhouette clothes. Cut of classical Japanese patterns combined with various historic elements in western costumes manages to emerge a perfect balance. Yamamoto is always challenged to produce different creation, in accordance with his ideology that the fashion worn by a person has to be able to express the person beyond just following the trend. Rei Kawakubo, who is a close friend of Yamamoto, is well known for her collection of 'Comme des Garcons', which explores deconstructive forms that is very different from the minimalist ideology. Her minimalism does not always appear effortless, instead requires thinking about materials utilization and exploration forms also that emphasizes the existence of the person who wears it rather than just following the trend.

Minimalism that is presented is a minimalist style that brings a new trend, unites the western and eastern style, so that this minimalist style over time can be accepted as an encounter culture. In this collection, designer tried to apply the minimalist pattern method in creating pattern-using Sumba woven. 
By adapting the minimalism pattern method into the weaving material, then at the next stage, designer produces silhouettes that are adjust to the weaving pattern. For example in women's fashion tops, designers use a square pattern with the aim of not cutting out the shape of the woven pattern. In the convex section the designer combines woven material with linen so that doesn't damage the weaving pattern. On the overall design, designer avoid in using curve pattern which can create left over material.

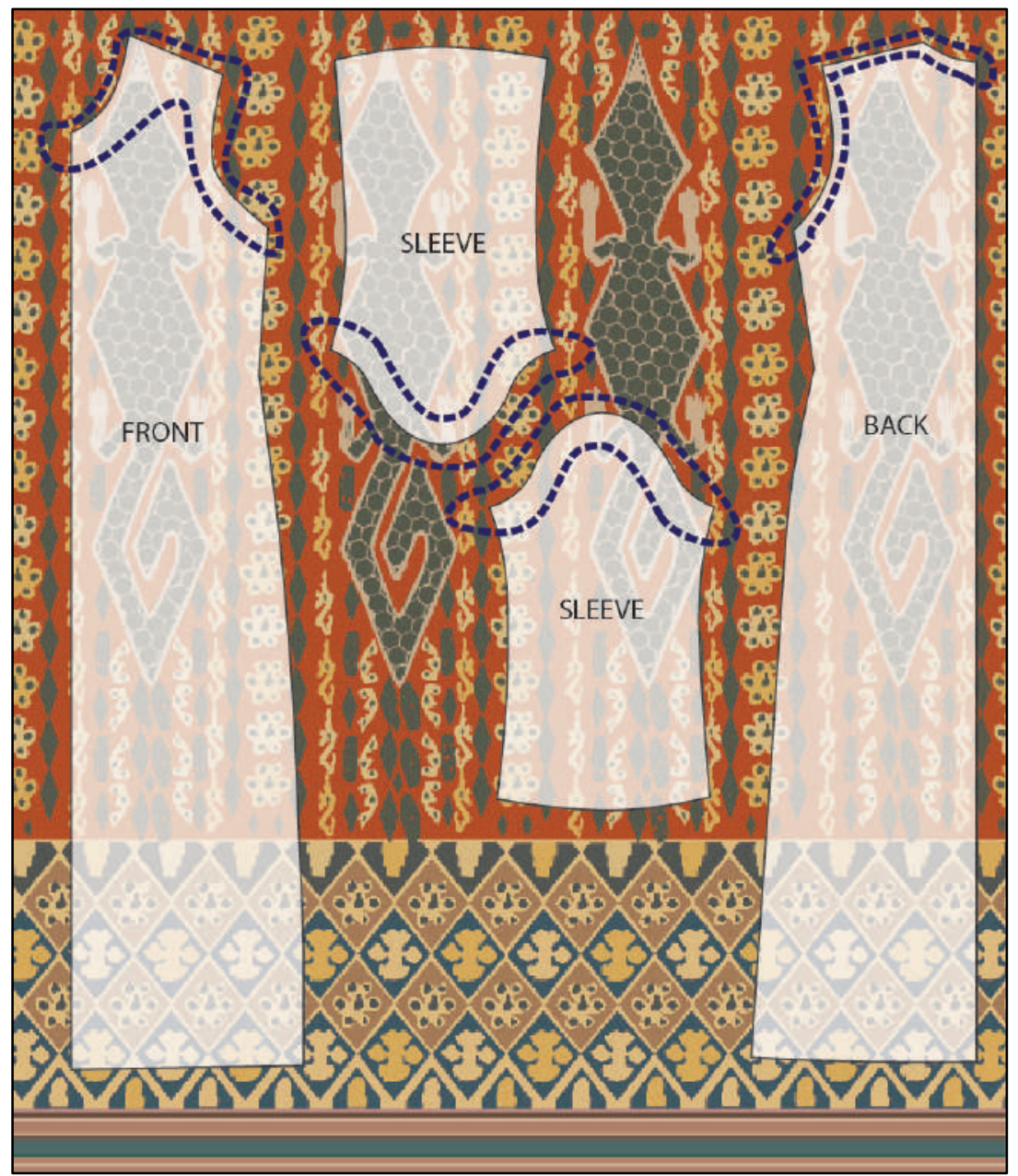

Figure 4. Technical drawing using regular pattern for Women clothes with Sumba Woven. Source: Ningsih, 2018

The picture above is the placement of regular woman tunic patterns on Sumba woven fabric. In the picture, it can be seen that the shape of the regular fashion patterns still use a form adapted from the shape of the human body, for example the rounded neck, decreased shoulder line, and curved shape of the arm. These formations are not in accordance with the character of the image of Sumba woven that highlights the image 
Serat Rupa Journal of Design, January 2019, Vol.3, No.1: 61-76

E-ISSN: 2477-586X, ISSN: 2338-3348 | https://doi.org/10.28932/srjd.v3i1.1056 | Received: 28-09-2018, Accepted: 25-01-2019 Yosepin Sri Ningsih

Revitalisation of Sumba Woven Into Fashion Product For Urban People As A Target Market

with a variety of large and small sizes images. As the result, images in Sumba woven can be cut not in the proper shape if the designer keep using the regular fashion pattern.

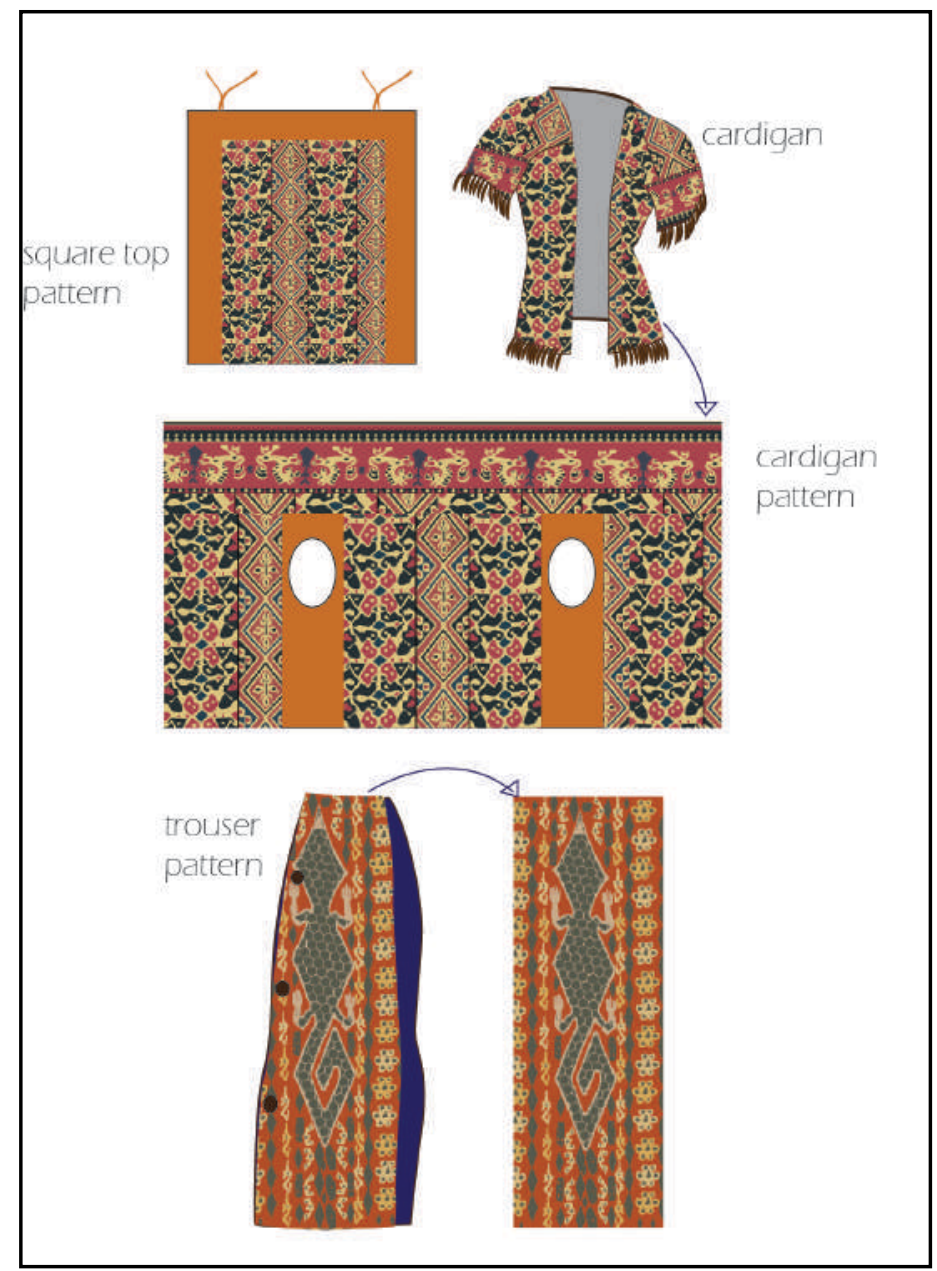

Figure 5. Technical drawing for Women clothes with Sumba Woven. Source: Ningsih, 2017

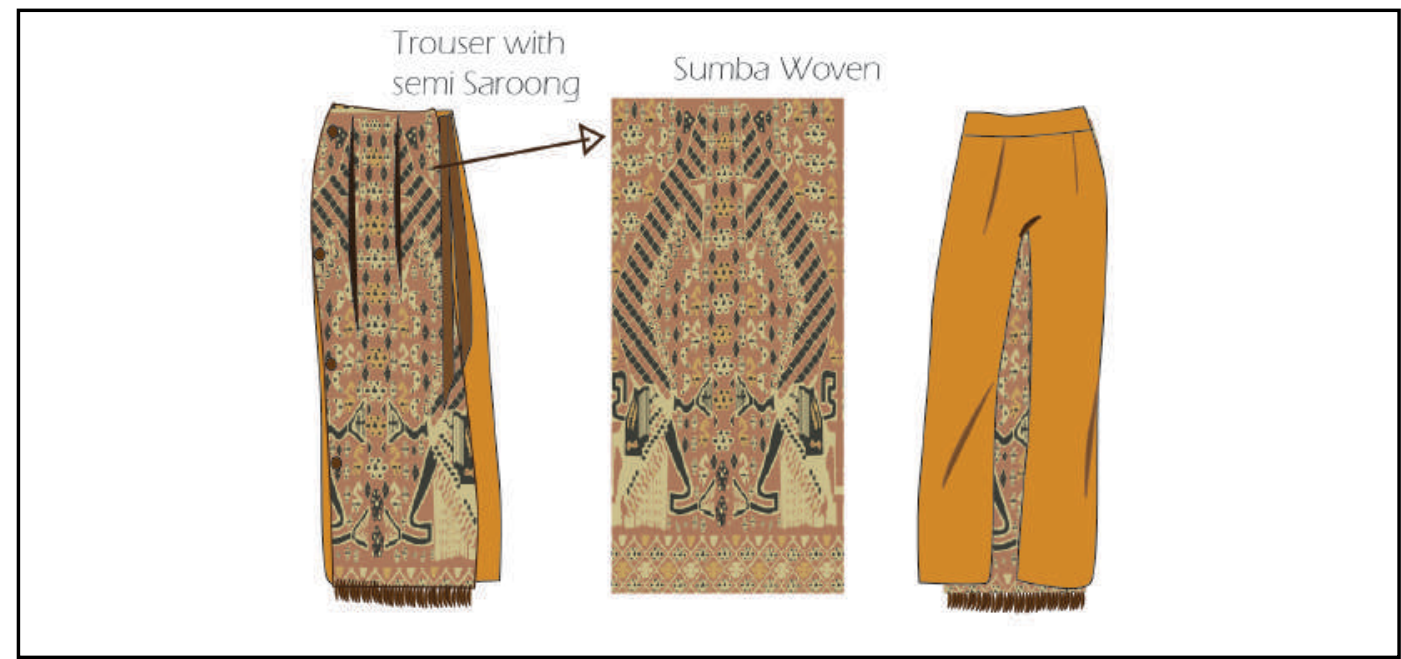

Figure 6. Technical drawing for men trouser with Sumba Woven. Source: Ningsih, 2017 


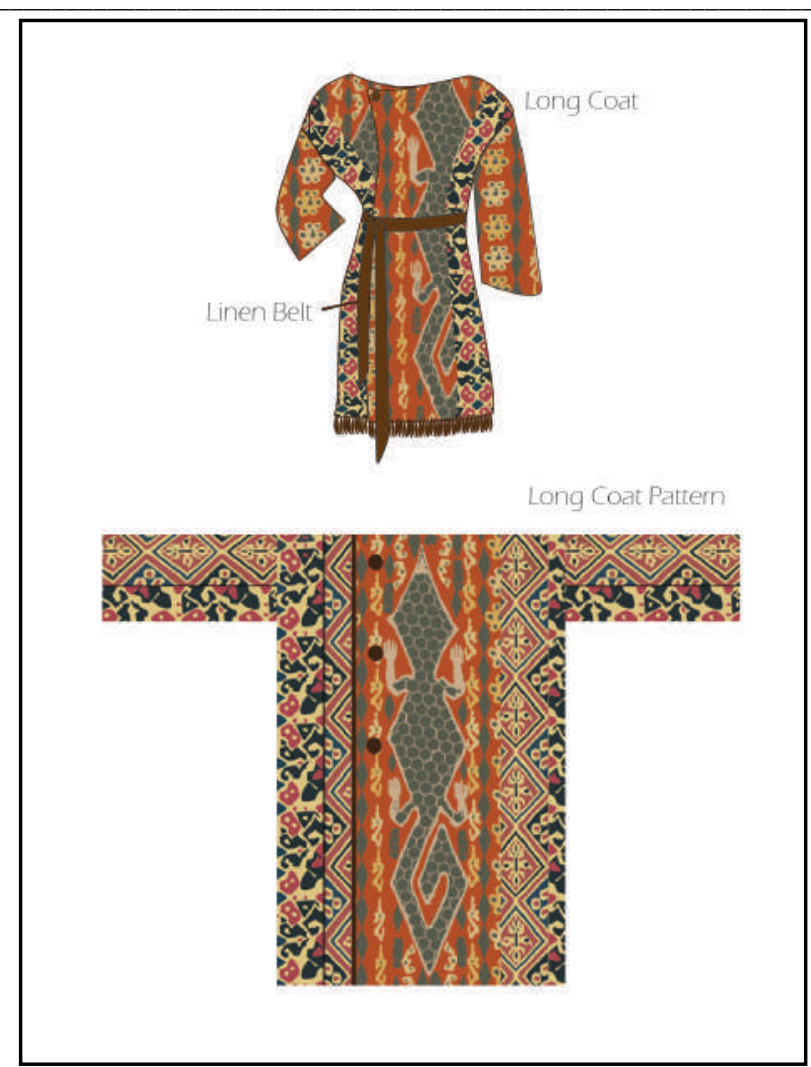

Figure 7. Technical drawing for men long coat with Sumba Woven. Source: Ningsih, 2017

\section{RESULTS AND DISCUSSION}

The designer, as the result product, presents fashion products entitled "Everyday with Sumba". The name of Everyday with Sumba was selected in accordance with the initial design goal, which was to bring traditional weaving from East Sumba out into a wider scope through fashion media, not limited in its local community only. The word "everyday" in the name of collection does not mean the consumers are supposed to wear clothes from Sumba weaving every day, but rather the designer intends to show that this East Sumba textile can be applied into formal and casual fashion forms so that it would be possible to be worn on daily basis activities. 


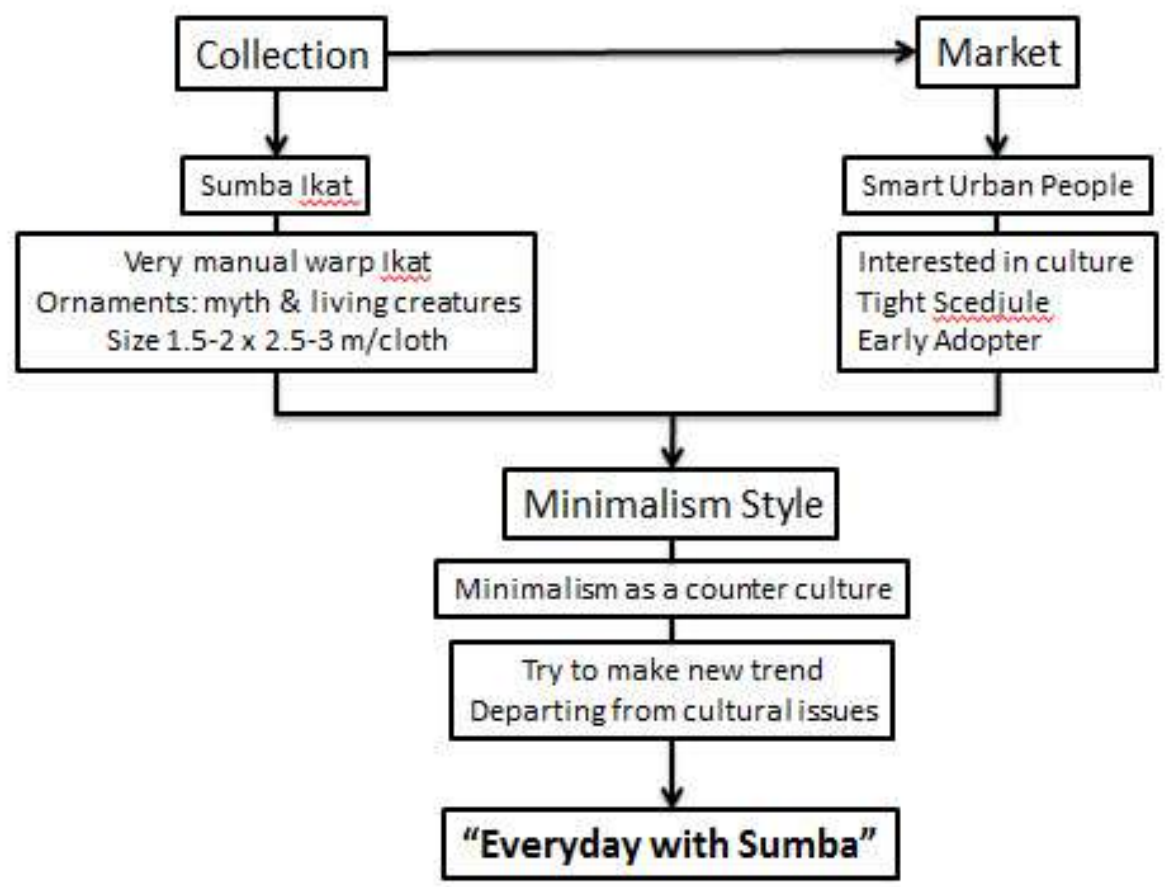

Figure 8. "Everyday with Sumba" Collection Scheme Source: Ningsih, 2017

Everyday with Sumba collection is targeted for middle to upper class urban people that are young spirited, smart, and having big interest in Indonesian culture. Another characteristic of the urban people is that they have a dense activity rhythm, yet they remain updated with the developments occurring in their surroundings, whether on technological, social, political, or also trending inclinations in various aspects of life. Based on that mobility consideration, the resulting clothing applies the silhouette of simple, classy, and easy to wear.

Using minimalism style approach, the silhouette presented was then translated into clothing pattern by applying the technique of maximally utilize pieces of fabric, which in this case was Ikat weaving from East Sumba. Because the designer utilized all pieces of fabric as much as possible, clothing pattern forms that were chosen should be adjusted with the complexion/ stripe forms, composition, and the size of Ikat weaving fabric. Large weaving complexion characters could be placed in the pattern areas that required larger size of fabric, such as the back area and front body area, while smaller pattern characters could be used as clothing detail accents such as for the arm area, edge of clothing, and underling combination. 
The collection presented is in the form of upper suit, lower suit, and also outer for men and women. Sumba weaving material has the character of natural, thicker but not rigid so that it can be combined with other materials that have natural touch character as well such as hemp cotton, linen, and other natural materials. Clothing cuttings utilized more than one type of Sumba fabric cloths by applying square cutting pattern method on certain parts so that no weaving material is wasted. This combining of various pattern types from different fabrics at the same time would also create new nuances for Sumba weaving.

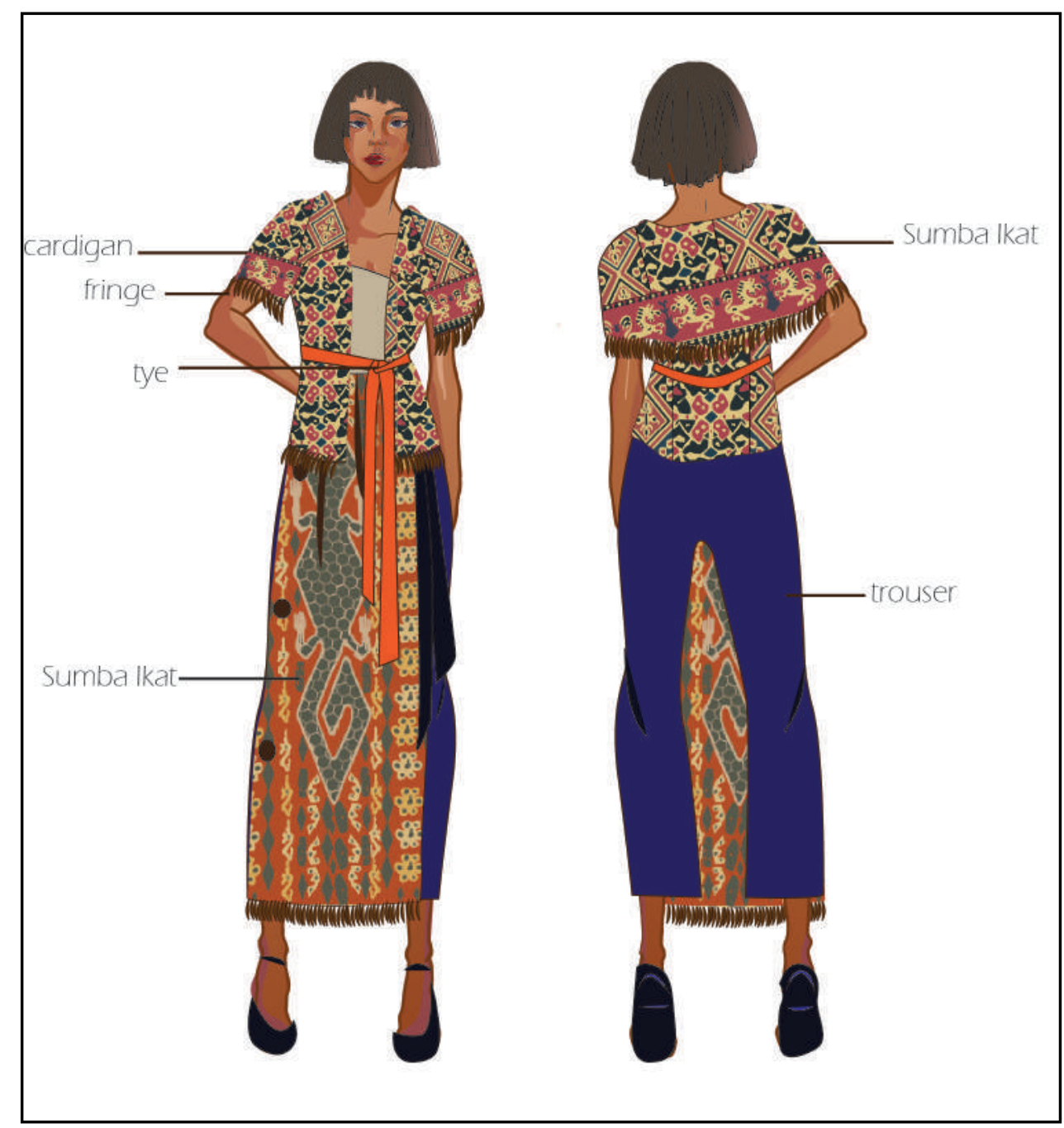

Figure 9. Collection "Everyday with Sumba" for woman with Cardigan and Trouser. Source: Ningsih, 2017 
Serat Rupa Journal of Design, January 2019, Vol.3, No.1: 61-76

E-ISSN: 2477-586X, ISSN: 2338-3348 | https://doi.org/10.28932/srjd.v3i1.1056 | Received: 28-09-2018, Accepted: 25-01-2019 Yosepin Sri Ningsih

Revitalisation of Sumba Woven Into Fashion Product For Urban People As A Target Market

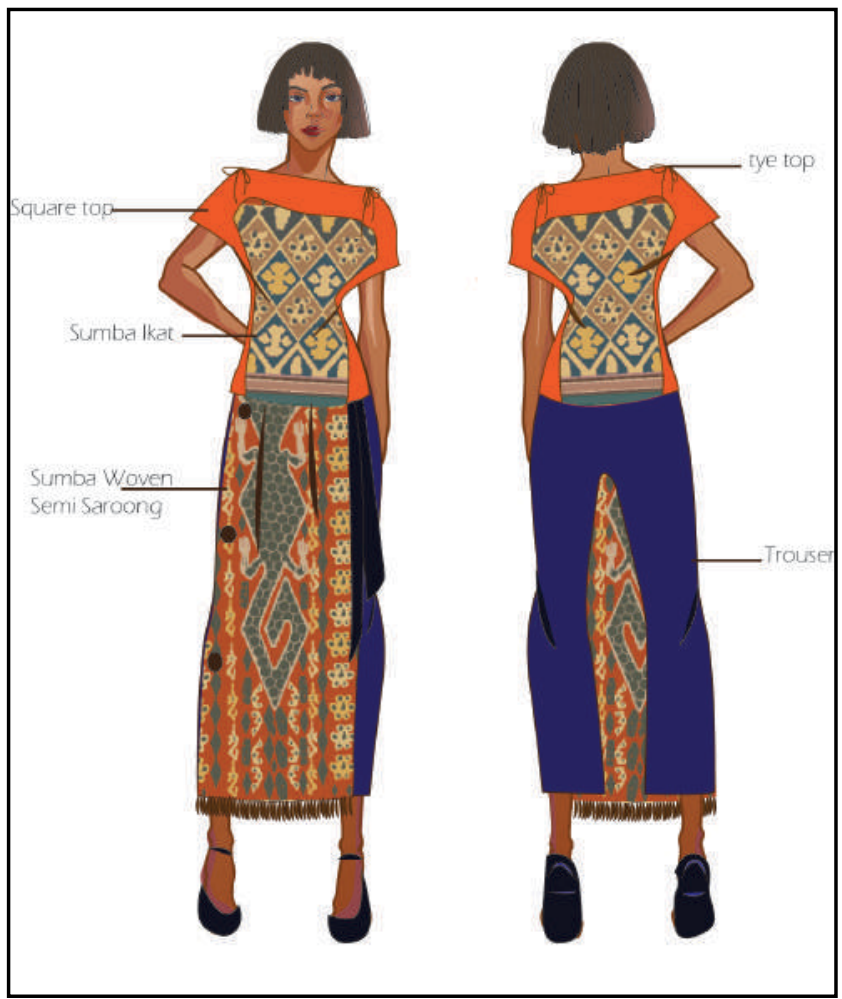

Figure 10.. Collection "Everyday with Sumba" for woman with Square Top and Trouser. Source: Ningsih, 2017

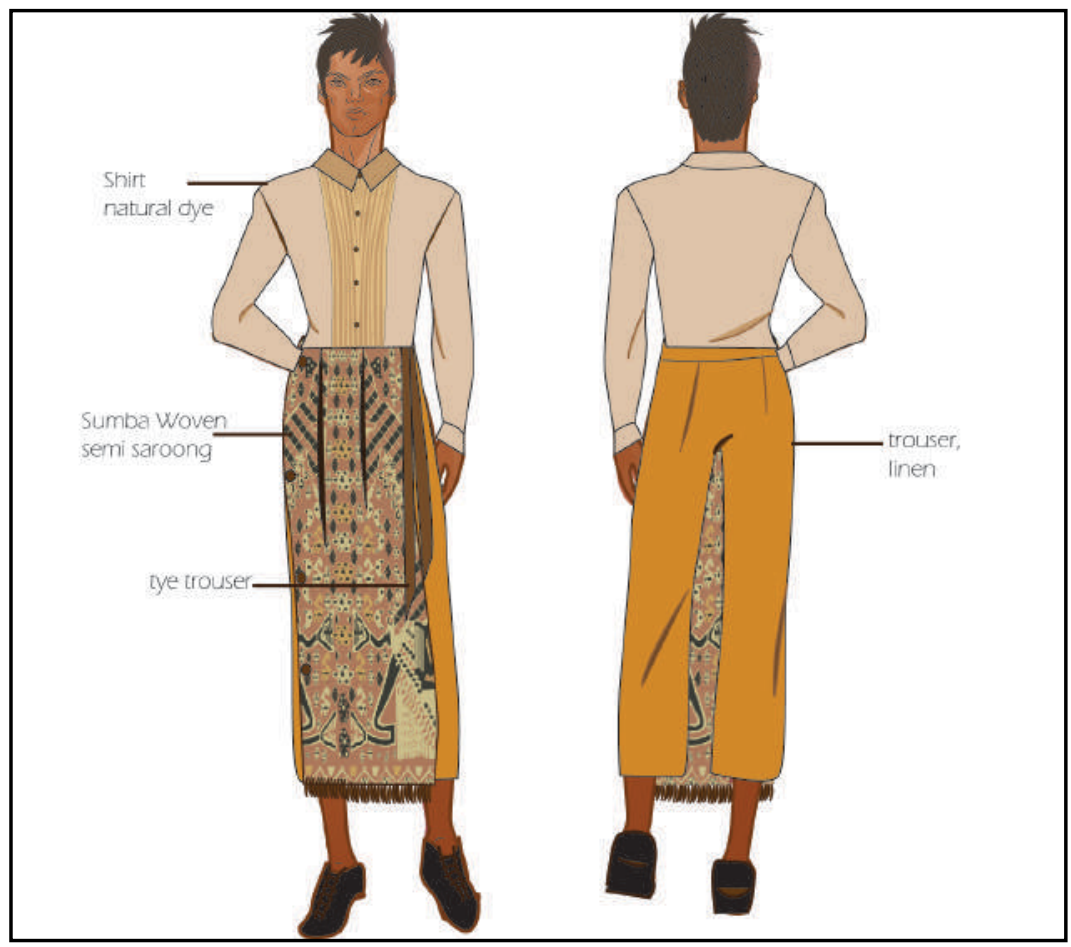

Figure 11. Collection "Everyday with Sumba" for man with Shirt and Trouser. Source: Ningsih, 2017 


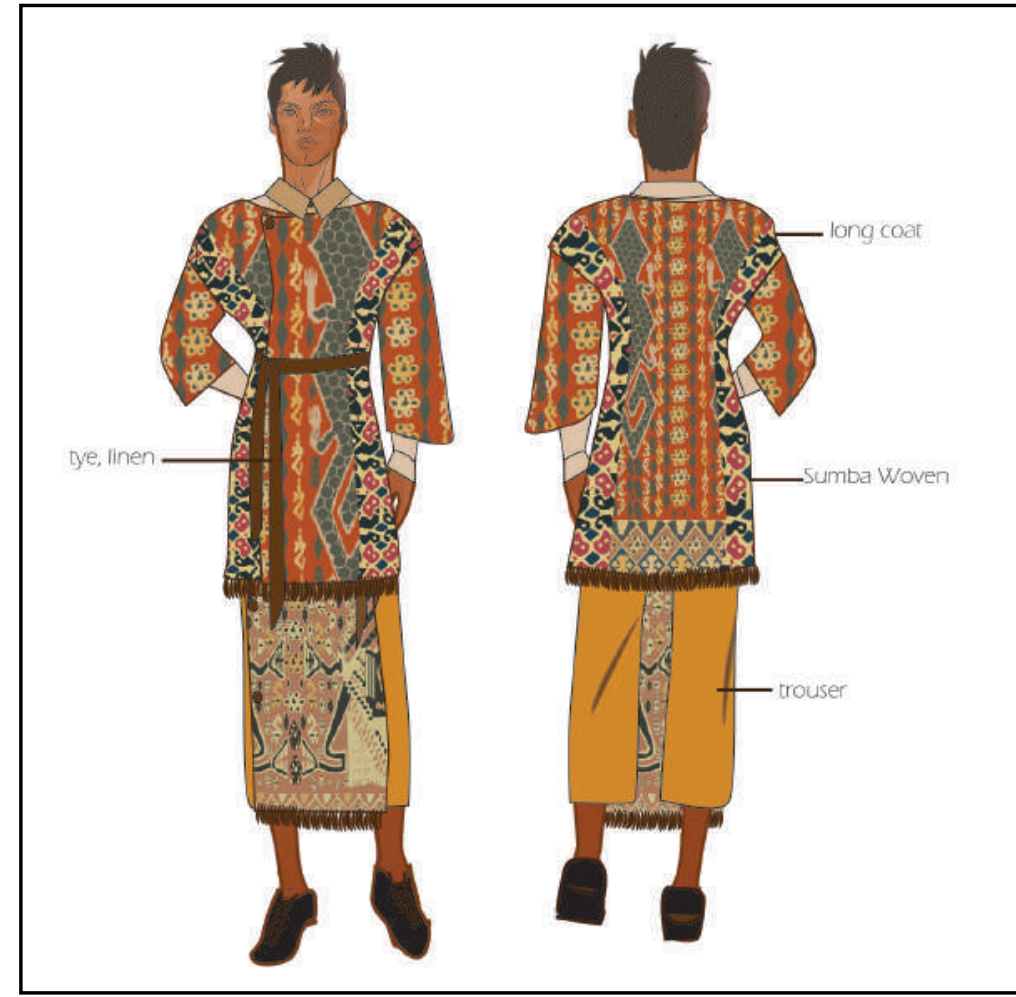

Figure 12. Collection "Everyday with Sumba" for man with Long Coat and Trouser. Source: Ningsih, 2017

\section{CONCLUSION}

In accordance with the time of this qualitative research, the purpose of this design process, which was to utilize the typical textiles from the NTT region, especially East Sumba through fashion media for urban people target market, has been presented by applying the minimalist style approach. Utilization of traditional textiles into products targeted for the urban people has its own challenges both from the textile characteristics and from the market trends. Designer had to understand those two aspects to be able to make products that would meet the market needs. Knowledge of the object of research became very important, especially about lkat weaving, whether on its meaning, manufacturing process, processing, and also its existence in the weaving origin society. Product deliverance to the market also needs to be embodied with the information of product maintenance and use.

The designer expects to be able to deliver valuable knowledge to potential customers through the resulting product. The production of fashion products by utilizing traditional textile for wider market is indirectly also a form of revitalization of local weaving. There is value addition especially on use and form value of Ikat weaving which previously was only in the form of fabric sheets that was mainly only used by local people on particular custom events, now has become ready to wear products that are more practical and can be used on daily basis. This product can also be an illustration of design reference for various 
Serat Rupa Journal of Design, January 2019, Vol.3, No.1: 61-76

E-ISSN: 2477-586X, ISSN: 2338-3348 | https://doi.org/10.28932/srjd.v3i1.1056 | Received: 28-09-2018, Accepted: 25-01-2019 Yosepin Sri Ningsih

Revitalisation of Sumba Woven Into Fashion Product For Urban People As A Target Market

agencies that obligate their employees to wear clothes those optimally utilizing traditional textiles without having to waste fabric.

\section{BIBLIOGRAPHY}

Book reference

Jay, S.E. (2014). TENUN, Handwoven Textiles of Indonesia. Cita Tenun Indonesia. Jakarta, Indonesia.

Knowles J. Gary \& Ardra L. Cole. (2008). Handbook of the ARTS in Qualitative Research. Sage. United States of America.

Maxwell, Robyn. (2003). Textiles of Southeast Asia: tradition, trade and transformation. Periplus. Singapore.

Miller, G. (2011). Indonesia Timur Tempo Doeloe 1544-1992. Komunitas Bambu. Jakarta, Indonesia.

Walker, Harriet. (2011). Less is More: Minimalism in Fashion. Merrell. London, United Kingdom.

Reference from research report

Ningsih, Y.S. (2017). Revitalisasi Produk Busana Dengan Material Utama Tenun Ikat Sumba Bagi Masyarakat Urban. Laporan penelitian, Universitas Kristen Maranatha.

Online reference

Lopulalan, Henry. (2014, May 21). "Nawa Cita", 9 Agenda Prioritas Jokowi-JK. Downloaded fromhttps://nasional.kompas.com/read/2014/05/21/0754454/.Nawa.Cita.9.Agenda. Prioritas.Jokowi-JK on 21 September 2016, 10.00 AM of West Indonesia Time.

Pollock, I. (2012). Ancient Emblems, Modern Cuts: Weaving and the State in Southeastern Indonesia. Textile Society of America Symposium Proceedings. University of Nebraska, Lincoln, America. Downloaded from https://digitalcommons.unl.edu on 10 September 2016, 11.00 PM of West Indonesia Time.

Map of East Nusa Tenggara Province. Downloaded from http://www.mapnall.com/id/PetaNusa-Tenggara-Timur_1104177.html on 21 September 2016, 09.16 AM of West Indonesia Time. 